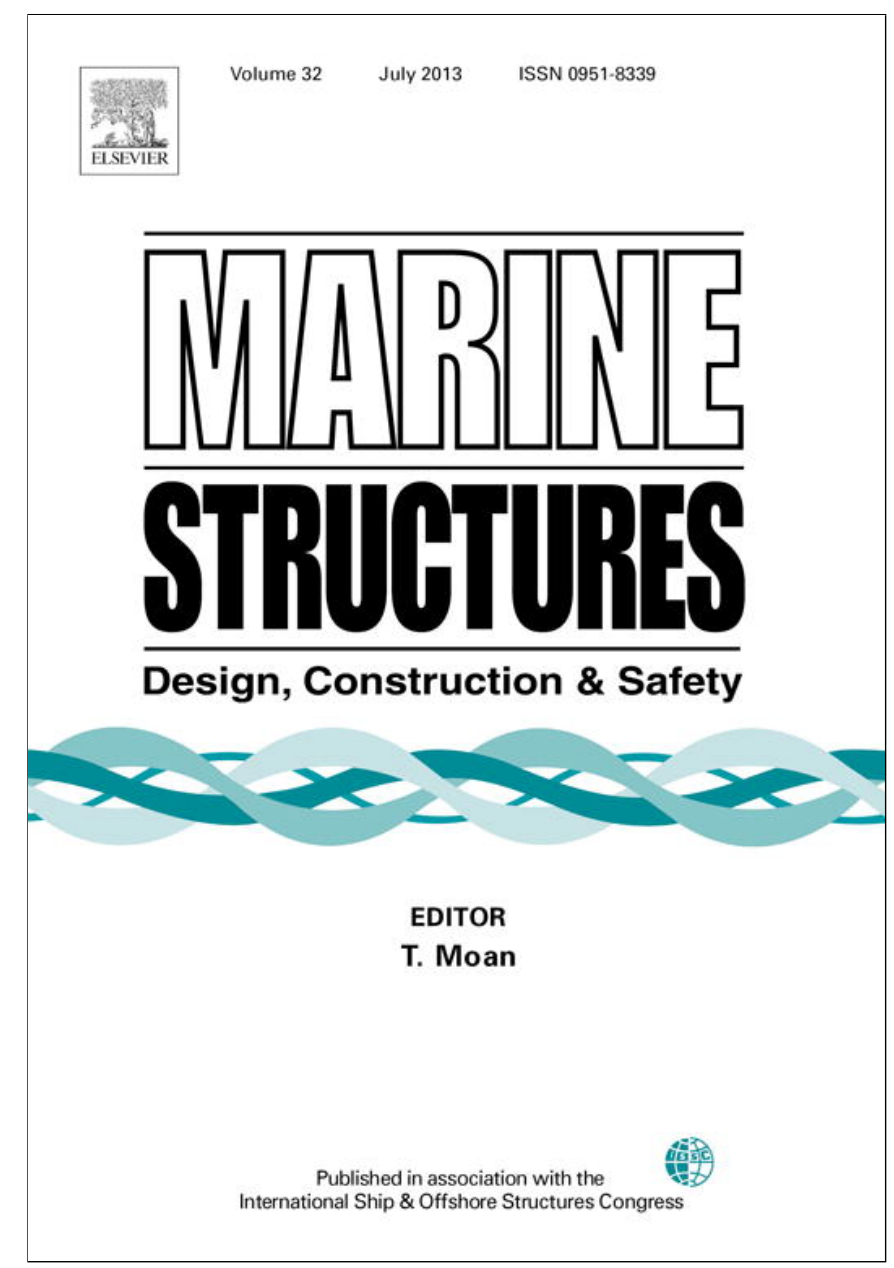

This article appeared in a journal published by Elsevier. The attached copy is furnished to the author for internal non-commercial research and education use, including for instruction at the authors institution and sharing with colleagues.

Other uses, including reproduction and distribution, or selling or licensing copies, or posting to personal, institutional or third party websites are prohibited.

In most cases authors are permitted to post their version of the article (e.g. in Word or Tex form) to their personal website or institutional repository. Authors requiring further information regarding Elsevier's archiving and manuscript policies are encouraged to visit: 


\title{
Reducing the cost of ballast tank corrosion: an economic modeling approach
}

\author{
Kris De Baere ${ }^{\mathrm{a}, *}$, Helen Verstraelen ${ }^{\mathrm{a}}$, Philippe Rigo ${ }^{\mathrm{b}}$, \\ Steven Van Passel ${ }^{\mathrm{c}, \mathrm{d}}$, Silvia Lenaerts ${ }^{\mathrm{c}}$, Geert Potters ${ }^{\mathrm{a}, \mathrm{c}}$ \\ ${ }^{a}$ Antwerp Maritime Academy, Noordkasteel Oost 6, B-2030 Antwerp, Belgium \\ b University of Liege, ANAST, Naval Architecture, Institut du Genie Civil, Bat. B52/3, Chemin des Chevreuils 1, \\ 4000 Liege 1, Belgium \\ ${ }^{\mathrm{c}}$ Department of Bioscience Engineering, University of Antwerp, Groenenborgerlaan 171, B-2020 Antwerp, \\ Belgium \\ d Centre for Environmental Sciences, Hasselt University, Agoralaan, 3590 Diepenbeek, Belgium
}

\section{A R T I C L E I N F O}

\section{Article history:}

Received 1 March 2012

Received in revised form 6 September 2012

Accepted 12 October 2012

\section{Keywords:}

Ballast tank

Total cost of ballast tanks

Corrosion

Corrosion resistant steel

Coating

Sensitivity analysis

\begin{abstract}
A B S T R A C T
One of the most relevant problems in ship construction and maintenance nowadays concerns the corrosion in the double hull space ballast tanks of modern merchant vessels. On the one hand, there is a general consensus that the economic life span of such a vessel depends primarily upon the corrosion state of its ballast tanks, while on the other hand, the position of these tanks, squeezed between the outer hull and the loading tanks, makes routine inspection and maintenance almost impossible.

Today, ship's ballast tanks are usually constructed in grade A steel and protected with a standard epoxy coating, backed up with sacrificial zinc anodes. Such a construction has been applied without significant alterations for many years. However, the objective of this economic study is to compare this construction method with some feasible alternatives. The considered alternatives are: (1) an increase of the scantlings, eliminating the necessity to replace corroded steel but diminishing the cargo carrying capacity of the ship, (2) application of the novel and more durable $\mathrm{TSCF}_{25}$ coating (3), the use of corrosion resistant steel in ship construction or (4) a standard PSPC $_{15}$ coating combined with lifetime lasting aluminum sacrificial anodes. After running each alternative through a cost model including an extensive sensitivity analysis, it is concluded that the durable coating and the use of
\end{abstract}

\footnotetext{
* Corresponding author. Tel.: +32 3205 6430; fax: +32 32250639.

E-mail address: kris.de.baere@hzs.be (K. De Baere).
} 
lifetime lasting aluminum anodes are bound to improve the actual basic tank concept. Corrosion resistant steel becomes attractive depending upon the evolution of the international steel market.

(c) 2013 Elsevier Ltd. All rights reserved.

\section{Introduction}

\subsection{The problem of ballast tank corrosion}

The degradation of metallic surfaces due to atmospheric corrosion is a well-known problem for many exposed steel structures such as bridges, storage tanks and pipelines. Bringing sea water into this equation causes an even more aggressive environment and an increased corrosion effect. Nevertheless, merchant vessels, carrying cargo all over the seven seas, make good use of this abundant commodity when necessary. In the absence of cargo, or when the ship is only partly loaded, a vessel carries seawater in her ballast tanks to ensure manoeuvrability and to control draft, stress and stability. As necessary as they are for the operation of a ship, though, the fact that ballast tanks are prone to corrosion, poses an important challenge for ship owners.

First of all, corrosion is expensive. For the U.S. economy alone, the 1998 cost of corrosion amounted to $\$ 275.7$ billion/year [1,2]. These economic losses were provoked by production interruptions, incidents and repairs. For the U.S. marine shipping industry, the annual corrosion-related costs are estimated at $\$ 2.7$ billion. This cost is divided into cost associated with new construction ( $\$ 1.12$ billion), with maintenance and repairs (\$810 million) [3], and with corrosion-related downtime (\$785 million; $[1,2])$. Secondly, corrosion impacts safety aboard. Statistics for ship hulls show that $90 \%$ of ship failures are attributed to corrosion [4].

Corrosion is a major cause of marine structural failures. Corrosion results in loss of structural strength at local and global levels, and leads to fatigue failure and stress corrosion cracking. Some recent marine incidents with tankers have been directly linked to accelerated corrosion [7]. Localized corrosion is among the major types of physical defects found largely on ship structures. The areas of the ship most susceptible to corrosion are the ballast tanks owing to the intense contact with seawater on both the sides, humidity, and the chloride-rich environment, even when empty. Because of the double hull configuration required by the Oil Pollution Act of 1990 [6-9], ballast tanks are difficult to maintain. The access is limited and the environment is unfriendly, the light is scarce, large parts are hard to reach, and the cost of decent maintenance is towering high, mainly because the working conditions are troublesome. In short, double hull ballast tanks act as the Achilles' heel of the ship.

The introduction of the double hull tankers in the nineties relocated all the structural elements from the cargo into the ballast tanks [7]. This configuration aggravates the corrosion problem on board. The quantity of corrosion in ballast tanks is therefore a decisive factor for ending the economic life of the ship and sending her to the scrap yard [10].

Today, ship's ballast tanks are constructed in grade A steel and protected with a standard epoxy coating and sacrificial zinc anodes at some locations. These serve to reduce and in some instances effectively defer corrosion and mitigate corrosion consequences [5]. Such a construction has been applied without significant alterations for decades. However, the goal of this study is to compare this traditional approach with some feasible alternatives through an analysis of the total cost, restricted to construction, exploitation and maintenance of the ballast tanks, hereinafter called total cost of ballast tanks (TCB). As such, the impact of any structural investments can be investigated in the conceptual stage of the vessel. Important elements in such an analysis are the design of the tank and the selection of appropriate construction, equipment and protection material.

\subsection{Research objective}

The objective of this study is to construct a cost-based model outlining the different bottlenecks in the construction of a double hull ship, minimizing corrosion effects during the economic lifetime of the ship (25 years). 
Based on this model, five different possibilities of ballast tank construction (cases I-V in Table 1) are compared, within the currently available techniques and materials, in order to obtain cost reductions. Selection of cases I-IV occurred on the basis of Safinah [11], case V is based on proper experience, information obtained during personal communications with the maintenance engineers of the port of Rotterdam and Gent and evidence of the rising popularity of aluminum as sacrificial material following an increasing ecologic, economic, legislative, and public health interest. [12]. The equations are applied to a typical Panamax tanker, a ship constructed according the size limits for ships travelling through the Panama Canal [13].

Case I concerns the typical tank as constructed today in ordinary grade A steel, $14 \mathrm{~mm}$ thickness, coated with a standard PSPC $_{15}$ coating [14] and equipped with zinc sacrificial anodes. Such a tank remains intact for approximately 5 years [15,16]; then the coating starts to degrade and corrosion appears requiring steel replacement and paint restoration in function of the time. The anodes have to be replaced every 5 years.

In case II, the core element is corrosion allowance. The corrosion allowance is the loss of steel thickness allowable due to corrosion, as laid down by her classification society, meaning that in the lifespan of a ship a certain quantity of corrosion is tolerable without endangering the structural integrity of the ship. As a rule of thumb, steel will be replaced, in dry dock, when its thickness has been reduced to $80 \%$ of the initial value. The present corrosion allowances of even the most conservative classification societies are marginally adequate for a 20-year design life vessel [17]. Hence, case II has been chosen to provide for an additional corrosion allowance of $3 \mathrm{~mm}$, As in case $\mathrm{I}$, a standard PSPC $_{15}$ coating is applied, and the anodes have to be replaced every 5 years.

In case III, ships receive the currently experimental $\mathrm{TSCF}_{25}$ coating on top of $14 \mathrm{~mm}$ grade $\mathrm{A}$ steel. This coating system is postulated to have a lifetime expectancy of 25 years, the economic lifetime of the ship, by a better preparation of the substrate, improved application conditions and an increased coating thickness [18,19]. Consequently, there is no more need for steel replacement, and coating repair needs are reduced. Since the surface attacked by corrosion is reduced, so will be the consumption of the sacrificial anodes. The anodes will be replaced only once every 10 years.

For case IV, the tanks are constructed in corrosion resistant steel (CRS) and painted with an esthetical white coating as per IMO PSPC 15 [14]. Coating repair remains necessary, although reduced. Anodes become redundant and are not used.

The case $\mathrm{V}$ tanks are again constructed in ordinary grade $\mathrm{A}$ steel and protected with a standard PSPC $_{15}$ epoxy coating. Cathodic protection is obtained by aluminum sacrificial anodes of sufficient mass to last 25 years, the full economic lifespan of the selected model.

\section{Methodology}

To assess the different possibilities a total cost of ballast tanks model is developed. In a next step, uncertainties are taken into account by a sensitivity analysis, including Monte Carlo sensitivity analysis. For each of the equations, Table 2 gives the applicable variables.

Table 1

Summary of the five cases in the analysis in terms of construction, equipment and maintenance criteria.

\begin{tabular}{llllll}
\hline & Case I & Case II & Case III & Case IV & Case V \\
\hline Steel & Grade A & Grade A & Grade A & Corrosion resistant & Grade A \\
Paint system & IMO PSPC $_{15}$ & IMO PSPC $_{15}$ & TSCF $_{25}$ & 1 Coat white epoxy & IMO PSPC $_{15}$ \\
Thickness & $320 \mu \mathrm{m}$ & $320 \mu \mathrm{m}$ & $350 \mu \mathrm{m}$ & $160 \mu \mathrm{m}$ & $320 \mu \mathrm{m}$ \\
Paint quality & Pure epoxy & Pure epoxy & Pure epoxy & Pure epoxy & Pure epoxy \\
Anodes & Yes $(\mathrm{Zn})$ & Yes $($ Zn $)$ & Yes $(\mathrm{Zn})$ & No & Yes $(\mathrm{Al})$ \\
Replacement of the anodes & Every 5 years & Every 5 years & Every 10 years & NA & Every 25 years \\
Coating repair & Yes & Yes & Yes & Yes & Yes \\
Increased scantlings & No & Yes & No & No & No \\
Steel replacement & Yes & NA & NA & NA & Yes \\
\hline
\end{tabular}


Table 2

TCB variables per model and per equation

\begin{tabular}{|c|c|c|c|c|c|}
\hline & Case I & Case II & Case III & Case IV & Case V \\
\hline \multicolumn{6}{|c|}{ 2.1.1 Initial investment - steel cost - Eqs. (3) and (4) } \\
\hline Surface area & Area & Area & Area & Area & Area \\
\hline Thickness & PT & $\mathrm{PT}+\mathrm{CA}$ & PT & PT & PT \\
\hline Density & DENS & DENS & DENS & DENS & DENS \\
\hline Cost new building steel & CAN & CAN & CAN & CNCRS & CAN \\
\hline \multicolumn{6}{|c|}{ 2.1.1 Initial investment - coating cost - Eq. (5) } \\
\hline Initial coating cost per $\mathrm{m}^{2}$ & $\mathrm{PSPC}_{15}$ & $\mathrm{PSPC}_{15}$ & $\mathrm{TSCF}_{25}$ & CCRS & $\mathrm{PSPC}_{15}$ \\
\hline \multicolumn{6}{|c|}{ 2.1.1. Initial investment - anode cost - Eq. (6) } \\
\hline Number of anodes & $\mathrm{ZA}$ & ZA & $\mathrm{ZA}$ & 1 & AA \\
\hline Initial installation cost per anode & IZA & IZA & IZA & 1 & IAA \\
\hline \multicolumn{6}{|l|}{ 2.1.2.1 Steel renewal cost - Eq. (9) } \\
\hline Lightweight & $\mathrm{LWT}_{\mathrm{T}}$ & 1 & & 1 & $\mathrm{LWT}_{\mathrm{T}}$ \\
\hline Cost of steel repair per ton & RAS & 1 & 1 & 1 & RAS \\
\hline \multicolumn{6}{|l|}{ 2.1.2.2 Coating repair cost - Eq. (11) } \\
\hline Surface & Area & Area & Area/2 & Area/4 & Area \\
\hline Cost of recoating per square meter & RPSPC & RPSPC & RTSCF & RCCRS & RPSPC \\
\hline \multicolumn{6}{|l|}{ 2.1.2.3 Anode replacement cost - Eq. (12) } \\
\hline Number of anodes & $\mathrm{ZA}$ & ZA & ZA & & AA \\
\hline Installation cost per anode & IZA & IZA & IZA & 1 & IAA \\
\hline \multicolumn{6}{|c|}{ 2.1.2.4 Cost of unavailability due to drydock - Eq. (14) } \\
\hline Factor $f$ & 1 & 2 & 4 & 4 & 1 \\
\hline Lightweight & $\mathrm{LWT}_{\mathrm{T}}$ & $\mathrm{LWT}_{\mathrm{TII}}$ & $\mathrm{LWT}_{\mathrm{T}}$ & $\mathrm{LWT}_{\mathrm{T}}$ & $\mathrm{LWT}_{\mathrm{T}}$ \\
\hline Time charter equivalent & $\mathrm{TC}$ & TC & $\mathrm{TC}$ & $\mathrm{TC}$ & TC \\
\hline Cost of dry dock per day & CDD & CDD & CDD & CDD & CDD \\
\hline \multicolumn{6}{|l|}{ 2.1.3 Residual value - Eq. (16) } \\
\hline Lightweight & $\mathrm{LWT}_{\mathrm{T}}$ & $\mathrm{LWT}_{\mathrm{TII}}$ & $\mathrm{LWT}_{\mathrm{T}}$ & $\mathrm{LWT}_{\mathrm{T}}$ & $\mathrm{LWT}_{\mathrm{T}}$ \\
\hline Value of scrap iron & $\mathrm{SCI}$ & $\mathrm{SCI}$ & $\mathrm{SCI}$ & SCRS & SCI \\
\hline
\end{tabular}

\subsection{TCB (total cost of ballast tanks)}

The TCB equals the initial investment plus the exploitation costs through 25 years minus the residual value when the ship is sold for scrap and with DR as discount rate.

$$
\mathrm{TCB}=\text { Initial investment }+\sum_{1}^{25} \frac{\text { exploitation cost }}{(1+\mathrm{DR})^{n}}-\frac{\text { residual value }}{(1+\mathrm{DR})^{25}}
$$

\subsubsection{Initial investment}

The initial investment for each of the cases can be calculated as follows:

Initialinvestment $=$ steelcost + coatingcost + anodecost

Steelcost $=$ lightweight Eq. $(4) \times$ costnewbuildingsteel

Lightweight $=$ surfacearea $\times$ thickness $\times$ density

Coatingcost $=$ surfacearea $\times$ initialcoatingcostperm ${ }^{2}$

Anodecost $=$ numberofanodes $\times$ initialinstallationcostperanode 


\subsubsection{Exploitation cost}

The calculation of the exploitation cost takes five elements into account: steel renewal cost, coating repair cost, the cost to replace the anodes, the cost of unavailability of the ship due to dry dock and (for case II ships) the loss of cargo carrying capacity due to an increased lightweight.

2.1.2.1. Steel renewal cost. Effective ship maintenance can only be carried out during dry docks. A ship has to visit dry dock two times every five years, during one of which steel and coating repair jobs are performed. A rough estimate of the steel renewal cost has been derived from data obtained from a population of 18 ships (Fig. 1), belonging to three separate shipping companies, willing to share their information on past maintenance repairs. These ships were maintained in a normal way and repairs had been carried out during every previous dry dock visit. The quantity of steel replaced during dry dock resulting from damage by corrosion, cracks and deformation but excluding accidents can be represented by the following regression [20]:

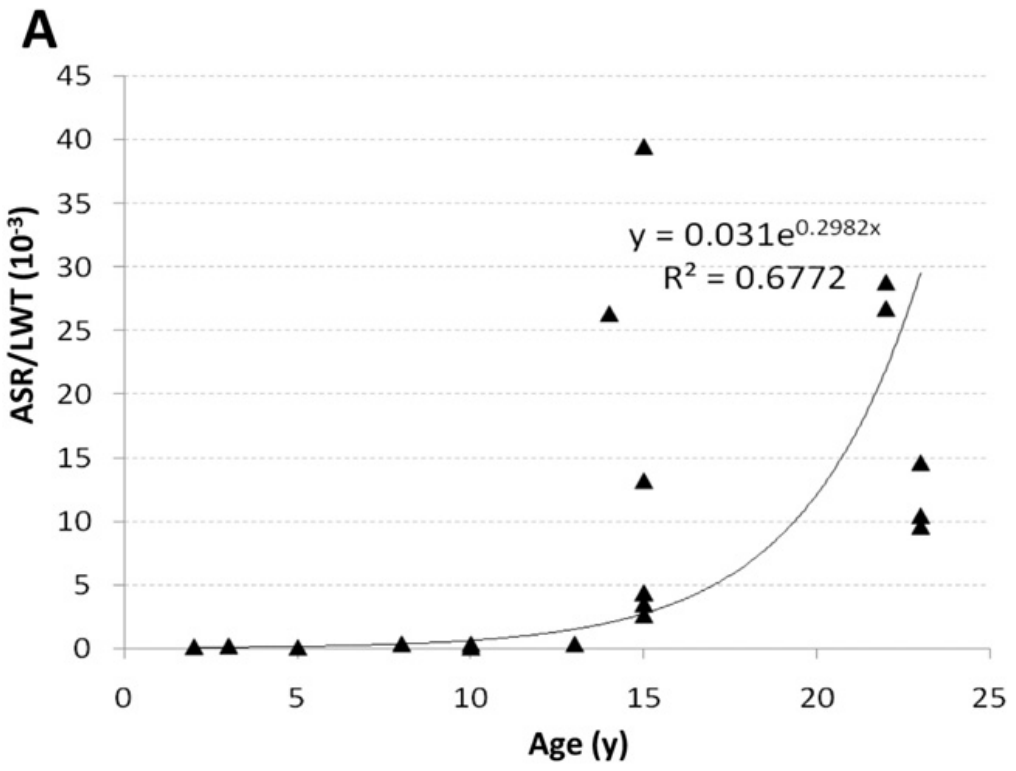

B

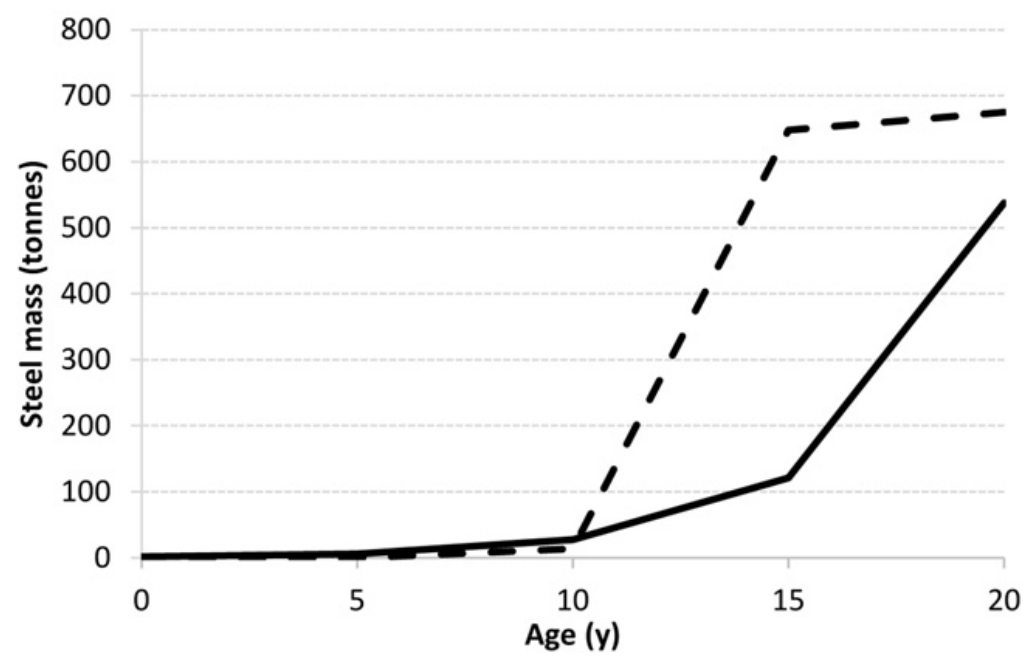

Fig. 1. (A) Quantity of steel in terms of the quantity of steel replaced per dry dock, per unit lightweight of the ship, in function of the age of the ship [20]. (B) Comparison of the predicted steel replacement according to Eq. (7) with the observed replacements by Løseth et al. [31]. Full line, own model (Eq. (7)) upsized to a VLCC of 300.000 DWT. Dashed line, data taken from [31], for a double hull VLCC, with the effect of maintenance taken into account. 


$$
\frac{\mathrm{ASR}}{\mathrm{LWT}}=0.031 e^{0.2982 t} \quad \text { or } \quad \mathrm{ASR}=\mathrm{LWT} \times 0.031 e^{0.2982 t}
$$

with ASR representing the quantity of steel replaced per dry dock and $t$ the age of the ship.

In this model, an important amount of scatter shows up for ships older than 15 years. Next to our in situ experience in the ballast tanks of more than 150 ships, this type of scatter turns out to be rather common among older ships, and the difference in the condition of the ballast tanks of two similar ships of the same age could be strikingly huge. This compares with the observations of Paik and Kim [21], the distribution of corrosion wastage statistics for any structural member is highly scattered at any corrosion exposure time and changes with time. Indeed, the condition of a ballast tank is not only agedependent but other important factors are involved such as substrate preparation, application conditions, mechanical damages, maintenance and many more. Moreover, when these observations are compared to other, previously published time dependent corrosion models [22-28], a similarly high variability can be noted for older ships.

However, data collected by Løseth et al. [29] can be used for a validation of Eq. (7) (Fig. 1). As it turns out, these data show a comparably large variation for steel renewal per dry dock for 15-year-old vessels, ranging from 6 to 1700 tons. To this end, it is necessary to reduce the total quantity of steel work per dry dock to the steel replacement exclusively imposed by corrosion. Steel repair work can be a consequence of deformations, corrosion and cracks. In the context of this research we are only interested in steel repair work inflicted by corrosion. A polynomial regression (Fig. 2) of the data obtained by Kawano and Hirakata [30] offers the following expression for the fraction of ASR/LWT caused exclusively by corrosion in function of the time, represented by $\mathrm{C} 1\left(R^{2}=0.911\right)$ :

$$
C 1=-0.0325 t^{3}+1.1299 t^{2}-4.465 t+1.1866
$$

Multiplication of Eq. (7) and Eq. (8) leads to the quantity of corroded steel to be replaced per drydock. Fig. 1 compares the results of this model with the observed steel replacements from [31]. An overall comparison of these data and Eq. (7) shows that there is hardly any difference, except in ships above an age of 20 years, which, as is stated further on, are not considered here either. Hence, Eq. (7) offers an acceptable description for corrosion-driven steel replacement in function of the age of a ship.

Finally, steel renewal cost can be calculated as follows:

$$
\begin{aligned}
\text { Steel renewal cost }= & 0.031 e^{0.2982 t} \times \text { light weight } \times\left(-0.0325 t^{3}+1.1299 t^{2}-4.465 t\right. \\
& +1.1866) \times \text { cost of steel repair per ton }
\end{aligned}
$$

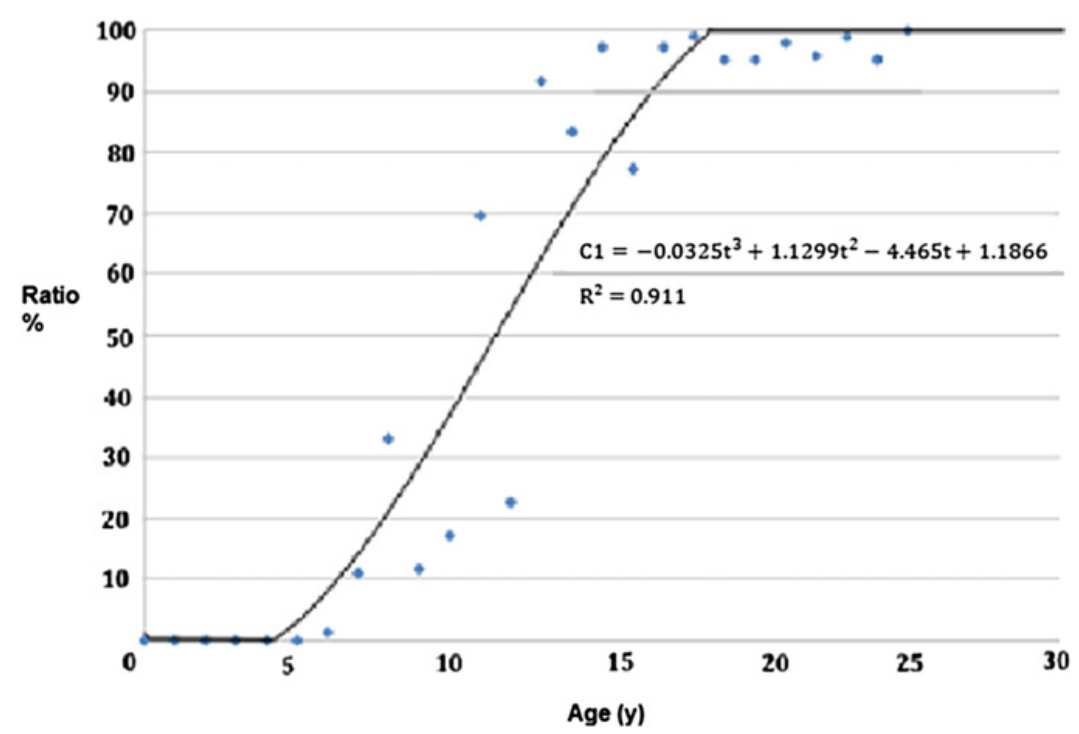

Fig. 2. $\mathrm{C} 1$ in function of the age of the ship (graphical presentation of numerical data presented by Kawano and Hirakata [30]). 
2.1.2.2. Coating repair cost. With regard to coating repair, the data presented in Verstraelen et al. $[15,16]$ offer a means to determine the percentage of the surface to be recoated, through the following equation:

$$
\mathrm{CI}=1.6817 t-7.1449
$$

With the corrosion index $\mathrm{CI}$ representing the surface of the coating damaged by corrosion in $\%$ and function of the time $[15,16]$. This formula shows that a coating remains nearly intact during approximately the five initial years. Afterwards the paint degrades in a nearly linear way with approximately $1.7 \%$ surface per year.

$$
\text { Coating repair cost }=\text { Surface } \times(1.6817 t-7.1449) \times \text { cost of recoating per square meter }
$$

At this moment $\mathrm{TSCF}_{25}$ is seldom applied and certainly not generally accepted by the shipping world as being the ultimate solution for the corrosion problem in ballast tanks (Damen Shipyard, 2011, pers. comm.). Consequently, statistical data on the effective lifetime of this coating are still lacking. The result of this study rests upon the basic assumption that the $\mathrm{TSCF}_{25}$ lives up the promised characteristics. When applying a $\mathrm{TSCF}_{25}$ (case III) instead of PSPC 15 the surface to be re-coated and number of dry-days to do this are diminished with $40 \%$ following the predicted lifetime of the coating system. For corrosion resistant steel (case IV) a similar reasoning is followed seen the nature of the substrate.

2.1.2.3. Anode replacement cost. Anodes should normally be replaced every 5 years. However, due to the expected good performance of the $\mathrm{TSCF}_{25}$ coating (case III), it can be surmised that replacement is only required once every 10 years. Tanks built in corrosion resistant steel (case IV) do not require any anodes at all. Case $V$ ships are equipped with aluminum sacrificial anodes lasting the economic lifespan of the ship. Anodes replacement is not considered.

Anode replacement cost $=$ number of anodes $\times$ installation cost per anode

2.1.2.4. Cost of unavailability of the ship due to dry dock. Time in dry dock as a consequence of corrosion is the sum of the time needed to replace the steel plus the time needed to restore the coating and replace the anodes.

The steel replacement time equals (Eq. (7) $\times$ Eq. (8)) divided by the yard capacity in t/day. Research (data obtained from 20 ship repair yards worldwide) revealed a huge variation in capacity ranging from 2 to 40 tons of steel per day. An average of $16.7 \mathrm{t} /$ day was calculated and rounded to $20 \mathrm{t} / \mathrm{day}$.

The calculation of the coating maintenance and repair time in dry dock is complicated since a lot of variables are involved. Maintenance is normally done at sea or in port by the crew while repair work in ballast tanks does not necessarily require the vessel to enter dry-dock, all the work can be done afloat at a repair base or at sea using a riding squad.

$$
\sum_{t=1}^{5}(1.6817(5 t)-7.1449)
$$

the algebraic sum of the outcome of (Eq. (10)) after 5, 10, 15, 20 and 25 years indicates that $90.4 \%$ of the coating is repaired during the complete lifecycle of the ship.

It would take typically two months dry-dock to recoat the ballast tanks completely (Kattan, Safinah Ltd., pers. comm). Moreover, the coating of a ship accounts for $12-25 \%$ (average 18.5\%) of the total man hours for the construction, with approximately $50 \%$ of the coated surface being inside the ballast tanks [32].

Applied to a Panamax tanker, which takes around $21 \mathrm{mh} / \mathrm{cgt}$ (manhour per compensated gross tonnage) to be built (Lloyds shipping economist, 2006), or, with a cgt of 21,000 [33], around 441,000 mh for the total construction and $41,000 \mathrm{mh}$ to (re)coat the ballast tanks. With three teams of 10 men working each three shifts of $10 \mathrm{~h}$ per day, this complete recoating is finished in 45 working days, which corresponds to the amount of time devoted to it in practice (Kattan, Safinah Ltd., pers. comm.). These 45 days will be divided following the appearance of corrosion as represented by Eq. (10) and over the 
major 5-year dry dock periods, as represented in Table 3. Finally, the time in excess of a standard dry dock of 6 days ([31], Antwerp Ship Repair, 2012, pers. comm.) is allocated to the corrosion problem.

Dry dock time can then be calculated according to Eq. (14):

$$
\begin{aligned}
\text { Dry dock time }= & {\left[\frac{\left[0.031 e^{0.2982 t} \times \text { lightweight } \times\left(-0.0325 t^{3}+1.1299 t^{2}-4.465 t+1.1866\right)\right]}{20}\right.} \\
& +\mathrm{DRC}]-6
\end{aligned}
$$

The equivalent cost then comes down to:

Dry dock cost $=[$ Dry dock time $\times($ Time Charter Equivalent + cost of dry dock per day $)]$

When applying a $\mathrm{TSCF}_{25}$ (case III) instead of $\mathrm{PSPC}_{15}$ the number of days is diminished with $40 \%$ following the predicted lifetime of the coating system. When using corrosion resistant (case IV) steel a similar reasoning is followed seen the nature of the substrate. In cases II, III and IV no dry dock time is provided for corroded steel replacement based on the fundamental assumptions of these alternative ways of construction.

2.1.2.5. Loss or gain of cargo carrying capacity due to an increased or decreased lightweight. A final exploitation cost, calculated in Eq. (16), is the loss of income (LI) due to an increased LWT as a consequence of the increase of the corrosion allowance. This cost is only applicable on board of the case II vessels. Increasing the corrosion allowance increases the lightweight of the ship while the cargo carrying capacity is diminished with the same amount. As this loss is only applicable during loaded voyages, the tanker is here supposed to be loaded $50 \%$ of the time [34].

$$
\mathrm{LI}=\frac{(\mathrm{TC} \times 365 \text { days })}{\text { total load }} \times\left(\mathrm{LWT}_{\mathrm{TII}}-\mathrm{LWT}_{\mathrm{T}}\right) \times 0.5
$$

For a preliminary assessment of the parameters linked to the use of corrosion-resistant steel (CRS), an experimental steel type was obtained (the characterization of which will be the focus of a future manuscript). A preliminary result indicates that this alloy corrodes 30\% slower than grade A ship construction steel. Additionally, a light-weight gain of $5 \%$ had to be factored in, based on a reduction of the corrosion allowance and the difference in density.

\subsubsection{Residual value}

After 25 years of service the ship is sold at the value of the scrap iron. As it is improbable that the higher concentrations of valuable alloys will influence the scrapping price, the same price can also be used for the tanks constructed in CRS (case IV). Residual value can then be calculated as follows:

$$
\text { Residual value }=\text { light weight } \times \text { value of the scrap iron }
$$

Table 3

Number of days needed for recoating in function of ship's age.

\begin{tabular}{ll}
\hline Moment of drydock (years) & Number of days re-coating (DRC) \\
\hline 5 & 0 \\
10 & 3 \\
15 & 9 \\
20 & 14 \\
25 & $19^{\mathrm{a}}$ \\
& \\
Total & 45 \\
\hline
\end{tabular}

\footnotetext{
${ }^{\mathrm{a}}$ Will not be taken into account since the ship is sold for scrap at that time.
} 


\subsection{Sensitivity analysis and Monte Carlo simulation}

\subsubsection{Sensitivity analysis}

To determine how the optimal solution, the minimum cost of the ballast tanks, is affected by multiple parameters a sensitivity analysis was carried out. Each of the parameters was varied and the variance of the real TCB analyzed.

\subsubsection{Monte Carlo simulation}

To examine how the TCB varies when the value of uncertain assumptions are modified, a Monte Carlo simulation was performed using the software program Crystal Ball (Oracle). When performing a Monte Carlo sensitivity analysis, probability distributions are specified for uncertain values of model input parameters. Then multiple trials are executed, taking each time a random draw from the distribution for each parameter. For each trial, the output is calculated for each set of specified values. When all the trials have been executed, a probability distribution of the model output is obtained [35].

By applying this risk model, not consequences but risks are compared and hence, more information is obtained as compared to when a conventional, static model is used. When probability distributions for several defined assumptions are specified, uncertainties are incorporated in the model. Moreover, the results of the model not only incorporate the uncertainties of the input parameters, they also give us their importance [36].

\section{Case study}

\subsection{Model selection}

The model selected for this study is a Panamax tanker. The maximum length overall (LOA - the total length of a ship's hull from the foremost to the aftermost points) of the ship is determined by the usable length of the locks being $304.8 \mathrm{~m}$. The maximum draft (12.04 $\mathrm{m}$ in tropical fresh water) is limited by the shallowest depth at the south sill of the Pedro Miguel locks and the maximum air draft of $57.91 \mathrm{~m}$ (at any state of the tide) is defined by the clearance under the Bridge of the America's at Balboa. The maximum width over outer surface of the shell plating is $32.31 \mathrm{~m}$. The deadweight of a Panamax ship varies between 50,000 and 80,000 Mt (DWT - total weight of cargo, crew, stores, ballast and bunkers on board a ship). Panamax ships can be considered as a good representation of the medium size merchant ship, representing approximately $48 \%$ of the world fleet [37].

More specifically, the calculations presented here are based on an average Panamax tanker of approximately 75,000 Mt DWT, an LOA of $228 \mathrm{~m}$, and a beam of $32.2 \mathrm{~m}$. As the sole interest of this study concerns the ballast tanks, all assessments are limited to the size and weight of the ballast tanks only. Starting point is the surface of the ballast tanks set at $51,000 \mathrm{~m}^{2}$ [34]. Furthermore, the ship is supposed to have been built in China and to have dry-dock inspections and repairs in Bahrain, due to the availability of recent, suitable and complete data. The economic life of the ship is set at 25 years. Afterwards the ship is sold for scrap iron.

\subsection{Calculations}

Table 4 represents the parameters used in the basic economic model as developed in Section 2. To this end, the parameters are sub-divided into three categories, viz. the values used to calculate (a) the lightweight of the tanks, (b) the initial investments and (c) the exploitation costs. For each parameter the acronym, a short description, the standard value and unit, source and formula and the type are indicated in the table.

Three types of variables can be distinguished. The first type gives parameters with a fixed value [F], determined by the selected generic Panamax tanker and constant in all further simulations. The second type shows the uncertain parameters [U]. During Monte Carlo analysis, these parameters will be allowed to vary according a certain probability distribution between a minimum and a 
Table 4

Parameters used in the economic model

\begin{tabular}{|c|c|c|c|c|}
\hline Acronym & Parameter & Value & Source \& formula & Type $^{a}$ \\
\hline \multicolumn{5}{|c|}{ Parameters used to calculate the lightweight of the tanks } \\
\hline Area & Surface of the ballast tanks & $51,000 \mathrm{~m}^{2}$ & {$[3,4]$} & $\mathrm{F}$ \\
\hline DWT & Deadweight & $75.000 \mathrm{t}$ & & $\mathrm{F}$ \\
\hline DENS & Density steel & $7.8 \mathrm{t} / \mathrm{m}^{3}$ & [48] & $\mathrm{F}$ \\
\hline PT & Plate thickness & $14 \mathrm{~mm}$ & Own measurements & $\mathrm{F}$ \\
\hline CA & Corrosion allowance & $3 \mathrm{~mm}$ & IACS CSR & $\mathrm{F}$ \\
\hline WA & Weight anodes Zn \& Al & $22 \mathrm{~kg}$ & Assumption & $\mathrm{F}$ \\
\hline $\mathrm{LWT}_{\mathrm{T}}$ & Lightweight tank I, III \& IV & $5569.2 \mathrm{t}$ & See Section 2.1 & $\mathrm{~F}$ \\
\hline $\mathrm{LWT}_{\mathrm{TII}}$ & Lightweight tank II & $6762.6 \mathrm{t}$ & See Section 2.1 & $\mathrm{~F}$ \\
\hline \multicolumn{5}{|c|}{ Parameters used to calculate the initial investment } \\
\hline $\mathrm{PSPC}_{15}$ & Initial coating PSPC $_{15}$ & $40 € / \mathrm{m}^{2}$ & [49] & $\mathrm{U}$ \\
\hline $\mathrm{TSCF}_{25}$ & Initial coating $\mathrm{TSCF}_{25}$ & $63 € / \mathrm{m}^{2}$ & $\begin{array}{l}\text { IHC, pers. comm. } \\
\text { TSCF }_{25}=\text { PSPC }_{15} \times 1.575\end{array}$ & $\mathrm{D}$ \\
\hline CCRS & Initial coating CRS & $35 € / \mathrm{m}^{2}$ & $\begin{array}{l}\text { Own estimation } \\
\text { CCRS }=\text { PSPC }_{15} \times 0.875\end{array}$ & $\mathrm{D}$ \\
\hline PZ & Price zinc & $4 € / \mathrm{kg}$ & {$[50]$} & $\mathrm{U}$ \\
\hline PA & Price aluminum & $8 € / \mathrm{kg}$ & {$[50]$} & $\mathrm{U}$ \\
\hline $\mathrm{ZA}$ & Number of zinc anodes & 325 & [34] & $\mathrm{F}$ \\
\hline IZA & Initial installation zinc anodes & $116 € /$ anode & $\mathrm{IZA}=(\mathrm{WA} \times \mathrm{PZ})+28 € /$ piece & $\mathrm{D}$ \\
\hline $\mathrm{AA}$ & Number of aluminum anodes & 477 & Own calculation & $\mathrm{F}$ \\
\hline IAA & Initial installation aluminum anodes & $204 € /$ anode & $\mathrm{IAA}=(\mathrm{WA} \times \mathrm{PA})+28 € /$ piece & $\mathrm{D}$ \\
\hline AS & Grade A steel purchase price & $900 € / \mathrm{t}$ & ArcelorMittal, 2009 & $\mathrm{U}$ \\
\hline RACRS & Ratio CRS versus grade $A$ & 1.3 & $30 \%$ > grade A; POSCO, pers. comm. & $\mathrm{U}$ \\
\hline CRS & CRS steel purchase price & $1170 € / \mathrm{t}$ & $\mathrm{CRS}=\mathrm{AS} \times \mathrm{RACRS}$ & $\mathrm{D}$ \\
\hline CAN & New building in grade $\mathrm{A}$ & $3150 € / \mathrm{t}$ & $\mathrm{CAN}=\mathrm{AS} \times 3.5$ & $\mathrm{D}$ \\
\hline CNCRS & New building in grade CRS & $4095 € / \mathrm{t}$ & $\mathrm{CNCRS}=\mathrm{CRS} \times 3.5$ & $\mathrm{D}$ \\
\hline$\$$ & Dollar exchange rate & $1 \$=0.68473 €$ & As per $26 / 04 / 2011$ & $\mathrm{~F}$ \\
\hline \multicolumn{5}{|c|}{ Parameters used to calculate the exploitation costs } \\
\hline RAS & Repair grade A steel & $7020 € / \mathrm{t}$ & $\mathrm{RAS}=\mathrm{AS} \times 7.8$ & $\mathrm{D}$ \\
\hline RPSPC & Repair PSPC $_{15}$ & $61.35 € / \mathrm{m}^{2}$ & $\begin{array}{l}\text { Terkels (ASR) \& Hoogenboom } \\
\text { (Hempel), pers. comm. } \\
\text { RPSPC }=\text { PSPC }_{15} \times 1.5338\end{array}$ & $\mathrm{D}$ \\
\hline RTSCF & Repair $\mathrm{TSCF}_{25}$ & $96.62 € / \mathrm{m}^{2}$ & $\begin{array}{l}\text { Own estimation } \\
\text { RTSCF }=\text { PSPC }_{15} \times 2.4156\end{array}$ & $\mathrm{D}$ \\
\hline RCCRS & Repair coating CRS & $53.8 € / \mathrm{m}^{2}$ & $\begin{array}{l}\text { Own estimation } \\
\text { RCCRS }=\text { PSPC }_{15} \times 1.345\end{array}$ & $\mathrm{D}$ \\
\hline $\mathrm{SCI}$ & Scrap per t grade A steel & $585 € / \mathrm{t}$ & $\mathrm{SCI}=\mathrm{AS} \times 0.65$ & $\mathrm{D}$ \\
\hline SCRS & Scrap per t CRS steel & $585 € / \mathrm{t}$ & $\mathrm{SCRS}=\mathrm{AS} \times 0.65$ & $\mathrm{D}$ \\
\hline CDD & Rental dry dock & $2885 € /$ day & [51] (LXBX0.5\$/day) & $\mathrm{U}$ \\
\hline TC & Time charter equivalent Panamax tanker & $15,514 € /$ day & [52] & $\mathrm{U}$ \\
\hline IR & Inflation rate & $2 \%$ & [37] & \\
\hline DR & Discount rate & $4 \%$ & {$[42,43]$ \& pers. comm. Notteboom } & $\mathrm{U}$ \\
\hline DRC & Days re-coating & & Own estimation & \\
\hline
\end{tabular}

${ }^{a} F$ are parameters with a fixed value determined by the selected model, $U$ are the parameters with a variable value (see Table 5 and $D$ are the parameters function of one or more other parameters (see source $\&$ formula column)).

maximum value and taking into account a most plausible value (see Table 5). The third type describes the parameters which are dependent [D] upon one or more other parameters of either other type.

The cost of steel renewal, coating repair, the replacement of anodes and the rental cost of the dry dock have been based on the price list of Bahrain ASRY dry docks of 2008 (http://www.asry.net). More recent prices were available from other dry dock facilities, but the set of Bahrain was the only complete list for the purposes of this study.

Fig. 3 shows the outcome of the basic economic model for each of the five cases based on the parameters given in Table 4 . The numbers represent real values, adjusted for an inflation of $2 \%$ and discounted with $4 \%$ (see Section 3.2.1). 
Table 5

Minimum, maximum and most plausible value of the uncertain parameters used during the Monte Carlo analysis together with the probability distribution.

\begin{tabular}{lllllll}
\hline Uncertain parameter & Symbol & Min. & Most plausible value & Max. & Model & Unit \\
\hline Initial cost PSPC coating & PSPC $_{15}$ & 40 & 45 & 60 & Normal & $€ / \mathrm{m}^{2}$ \\
Grade A steel (basic price) & AS & 900 & 1000 & 1500 & Normal & $€ / \mathrm{t}$ \\
Ratio CRS versus grade A & RACRS & 1.2 & 1.3 & 1.5 & Normal \\
Drydock/day & CDD & 2597 & 2885 & 3174 & Normal & $€ /$ day \\
Time charter equivalent & TC & 13,963 & 15,514 & 17,065 & Normal & $€ /$ day \\
Price zinc & PZ & 4 & 5 & 6 & Normal & $€ / \mathrm{kg}$ \\
Price aluminum & PA & 8 & 10 & 12 & Normal & $€ / \mathrm{kg}$ \\
Inflation rate & IR & 0.9 & 2 & 3.8 & Normal & $\%$ \\
\hline
\end{tabular}

\subsubsection{Financial parameters used throughout the calculations}

3.2.1.1. Inflation adjustment factor. The result of the model, the sensitivity analysis and the Monte Carlo simulation are real cost. An inflation adjustment factor $(1+P)^{-t}$ was applied. $P$ is the inflation per year and $t$ is the age of the tank. Based on the Harmonized Indices of Consumer Prices (HICP) as published by Eurostat [37] for the European Union for the period December 1997 till June 2012, $P$ was assumed to to vary between 0.9 and 3.8 with an average value of $2 \%$ [38,39].

3.2.1.2. Steel price. The steel price is rising steeper than the $2 \%$ per annum taken into account by the general inflation rate (see Section 3.2.1.1). This increase in price is caused firstly by the increasing scarcity of raw materials, especially given the growing demand in China. Moreover, the fabrication of ship construction steel is energy consuming and energy is getting ever more expensive. An increase of 8.6\% per year was observed for hot rolled steel for the Asian market in a period from August 2005 till April 2011 [40]. Hence, an increase of 6\% was incorporated in the model. However, a changing price of grade A means that the price of CRS, steel repair work and scrap are supposed to vary in parallel.

3.2.1.3. Discount rate. Generally, low discount rates favour projects with the highest total benefits while high SDRs rates favour projects where the benefits are front-end loaded. Based on the European Commission [41] (social cost-benefit $2 \%$ and private investments $15 \%$ ) a discount rate of $4 \%$ was chosen.

This figure is backed up by an analysis of similar, maritime, investments. Eijgenraam et al, mention in their directives for CBA that the real discount rate should equal average interest rate for risk-free long-term loans on the capital market [42]. The figure they put forward is $4 \%$ per annum. Pearce et al. also prefer to use a standard discount real discount rate of $4 \%$ based on social time preference $[43,44]$. And the cost and benefits analysis of major harbor projects in Flanders and the Netherlands, such as Maasvlakte 2, uses a $4 \%$ discount rate as well (Notteboom, pers. comm.). A sensitivity analysis of

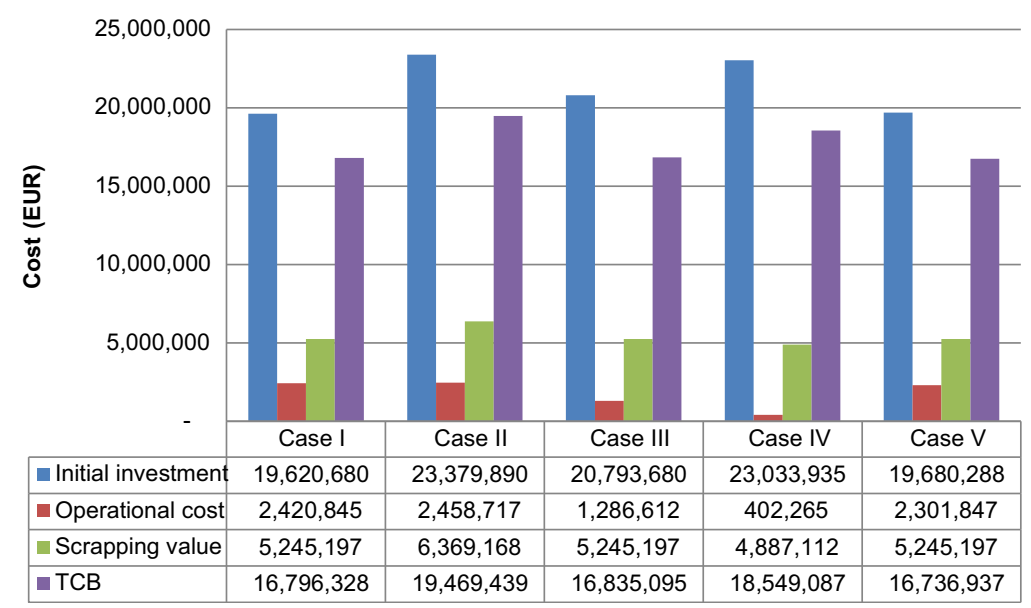

Fig. 3. Results of the basic model for each of the five cases, inflated with $2 \%$ and discounted with $4 \%$ per year. 
the impact of the discount rate (data not shown) indicates that, although absolute values in the outcome of the calculations change, there is no effect on the differences between the different cases that are analysed in this text.

\section{Results and discussion}

\subsection{Model results}

Comparison of the TCB results in Fig. 3 shows the cases I, III, and V to be very competitive, whereas, in case II, expanded scantlings might well offer adequate protection against corrosion, but are counterbalanced by the high penalty of an increased loss of cargo carrying capacity. This conclusion is confirmed by Psarros [45] and Eliasson [46] who state that it is possible to build ships with such thick steel that even with free corrosion taking place the ship would have enough strength left to perform its designed service life. It is generally agreed today that this is no longer a cost efficient way to build and operate ships.

However, the outcome of cases III, V and even IV increases the number of choices available to the ship owner. A few years ago the classic combination of grade A steel protected with a PSPC $_{15}$ system coating and backed up with sacrificial anodes, would not have been questioned. This study shows that today it is may be worthwhile to take alternatives III, IV or V into consideration. A sensitivity and Monte Carlo analysis is therefore well placed to shed more light on which parameters are most decisive.

\subsection{Sensitivity analysis}

The only parameters with a substantial impact on the TCB are the steel- and coating price. All the other parameters have a negligible relative or absolute importance.

Table 6 represents the impact of a change in steel price and coating cost on the real value of the TCB and the relative ranking of the cases. The values used in the original basic economic model are in cells

\section{Table 6}

Influence on the real TCB of the evolution of the steel price and coating cost. Cells with grey shading refer to values used in the basic model.

\begin{tabular}{|c|c|c|c|c|c|}
\hline \multicolumn{6}{|l|}{ TCB in $€$} \\
\hline \multicolumn{6}{|l|}{ Steel price } \\
\hline \multirow[t]{2}{*}{$-50 \%$} & Case V & Case I & Case IV $10,368,176$ & Case III & Case II \\
\hline & $10,168,501$ & $10,227,892$ & & $10,686,203$ & $12,002,928$ \\
\hline \multirow[t]{2}{*}{$-25 \%$} & Case V & Case I & Case III & Case IV & Case II \\
\hline & $13,452,719$ & $13,512,110$ & $13,760,649$ & $14,458,632$ & $15,736,183$ \\
\hline \multirow[t]{2}{*}{900 EURO/ton } & Case V & Case I & Case III & Case IV & Case II \\
\hline & $16,736,937$ & $16,796,328$ & $16,835,095$ & $18,549,087$ & $19,469,439$ \\
\hline \multirow[t]{2}{*}{$+25 \%$} & Case III & Case V & Case I & Case IV & Case II \\
\hline & $19,909,540$ & $20,021,155$ & $20,080,546$ & $22,639,543$ & $23,202,694$ \\
\hline \multirow[t]{2}{*}{$+50 \%$} & Case III & Case V & Case I & Case IV & Case II \\
\hline & $22,983,986$ & $23,305,373$ & $23,364,764$ & $26,729,999$ & $26,935,949$ \\
\hline \multirow[t]{2}{*}{$+100 \%$} & Case III & Case V & Case I & Case II & Case IV \\
\hline & $29,132,877$ & $29,873,809$ & $29,933,200$ & $34,402,460$ & $34,910,910$ \\
\hline \multicolumn{6}{|l|}{ Cost of coating } \\
\hline \multirow[t]{2}{*}{$-50 \%$} & Case III & Case V & Case I & Case IV & Case II \\
\hline & $14,628,568$ & $15,081,953$ & $15,141,344$ & $17,322,494$ & $17,814,455$ \\
\hline \multirow[t]{2}{*}{$-25 \%$} & Case III & Case V & Case I & Case IV & Case II \\
\hline & $15,731,832$ & $15,909,445$ & $15,968,836$ & $17,935,791$ & $18,641,947$ \\
\hline \multirow[t]{2}{*}{$\mathrm{PSPC}_{15}$ at $40 \mathrm{EURO} / \mathrm{m}^{2}$} & Case V & Case I & Case III & Case IV & Case II \\
\hline & $16,736,937$ & $16,796,328$ & $16,835,095$ & $18,549,087$ & $19,469,439$ \\
\hline \multirow[t]{2}{*}{$+25 \%$} & Case V & Case I & Case III & Case IV & Case II \\
\hline & $17,564,429$ & $17,623,820$ & $17,938,358$ & $19,162,384$ & $20,296,930$ \\
\hline \multirow[t]{2}{*}{$+50 \%$} & Case V & Case I & Case III & Case IV & Case II \\
\hline & $18,391,921$ & $18,451,312$ & $19,041,621$ & $19,775,681$ & $21,124,422$ \\
\hline
\end{tabular}


with grey shading. Cases are ranked from left to right with ascending TCB value. The influence of a change in steel- and coating price is mainly absolute. The relative impact is limited. The difference between I, III and V remains small and nearly unaffected by the two studied parameters. It is inevitable that the price of raw materials, such as ship construction steel, grade A as well as CRS, will rise in the future. The increased scantling method and the construction in CRS will lose ground compared to the cases were the protection of the tanks is based on coating and sacrificial anodes.

Table 7 represents the influence of cost ratio's CRS to grade A steel and PSPC $_{15}$ to TCSF $_{25}$ and the discount on the relative ranking of the cases. It is not surprising that when CRS becomes more expensive compared to grade A steel, the position of case IV becomes less favorable. Additionally, the impact of the relation between the cost of $\mathrm{TSCF}_{25}$ and $\mathrm{PSPC}_{15}$ is not sufficiently important to influence the relative position of the cases significantly. Only when the price of the TSCF $_{25}$ system drops, case III becomes attractive. The second part of Table 7 shows the influence of the cost of coating. When application of a coating becomes cheaper, the use of sophisticated coating systems (case III) is favored compared to the standard PSPC 15 coating.

\section{Monte Carlo analysis}

\subsection{Input parameters}

As indicated in Section 3.2, the parameters used in the Monte Carlo analysis are divided into three categories. The fixed parameters are model dependent, the dependent parameters are a function of one or more other values and the uncertain parameters are allowed to vary according a certain probability distribution. For all of the uncertain parameters a triangular distribution was selected. Minimum and maximum values and most probable value are listed in Table 5.

\subsection{Results of the Monte Carlo analysis}

The bar graphs in Fig. 4 show the median value of the real total cost of ballast tanks (TCB) after 5000 trials. Statistical data and sensitivity analysis are shown in Tables 8 and 9. Table 8 gives the complete

\section{Table 7}

Influence on the real TCB of the price ratio's of CRS to grade A steel and $\mathrm{TSCF}_{25}$ to $\mathrm{PSPC}_{15}$. Cells with grey shading refer to values used in the basic model.

\begin{tabular}{|c|c|c|c|c|c|}
\hline \multicolumn{6}{|c|}{$\mathrm{TCB}$ in $€$} \\
\hline \multicolumn{6}{|c|}{ Ratio cost CRS to grade A steel } \\
\hline \multirow[t]{2}{*}{1} & Case IV & Case V & Case I & Case III & Case II \\
\hline & $13,645,487$ & $16,736,937$ & $16,796,328$ & $16,835,095$ & $19,469,439$ \\
\hline \multirow[t]{2}{*}{1.1} & Case IV & Case V & Case I & Case III & Case II \\
\hline & $15,280,021$ & $16,736,937$ & $16,796,328$ & $16,835,095$ & $19,469,439$ \\
\hline \multirow[t]{2}{*}{1.2} & Case V & Case I & Case III & Case IV & Case II \\
\hline & $16,736,937$ & $16,796,328$ & $16,835,095$ & $16,914,554$ & $19,469,439$ \\
\hline \multirow[t]{2}{*}{1.3} & Case V & Case I & Case III & Case IV & Case II \\
\hline & $16,736,937$ & $16,796,328$ & $16,835,095$ & $18,549,087$ & $19,469,439$ \\
\hline \multirow[t]{2}{*}{1.4} & Case V & Case I & Case III & Case II & Case IV \\
\hline & $16,736,937$ & $16,796,328$ & $16,835,095$ & $19,469,439$ & $20,183,621$ \\
\hline \multirow[t]{2}{*}{1.5} & Case V & Case I & Case III & Case II & Case IV \\
\hline & $16,736,937$ & $16,796,328$ & $16,835,095$ & $19,469,439$ & $21,818,154$ \\
\hline \multicolumn{6}{|c|}{ Ratio cost $\mathrm{TSCF}_{25}$ to $\mathrm{PSPC}_{15}$} \\
\hline \multirow[t]{2}{*}{1.4} & Case III & Case V & Case I & Case IV & Case II \\
\hline & $16,478,095$ & $16,736,937$ & $16,796,328$ & $18,549,087$ & $19,469,439$ \\
\hline \multirow[t]{2}{*}{1.575} & Case V & Case I & Case III & Case IV & Case II \\
\hline & $16,736,937$ & $16,796,328$ & $16,835,095$ & $18,549,087$ & $19,469,439$ \\
\hline \multirow[t]{2}{*}{1.6} & Case V & Case I & Case III & Case IV & Case II \\
\hline & $16,736,937$ & $16,796,328$ & $16,886,095$ & $18,549,087$ & $19,469,439$ \\
\hline \multirow[t]{2}{*}{1.8} & Case V & Case I & Case III & Case IV & Case II \\
\hline & $16,736,937$ & $16,796,328$ & $17,294,095$ & $18,549,087$ & $19,469,439$ \\
\hline
\end{tabular}


TCB after 5000 MC trials

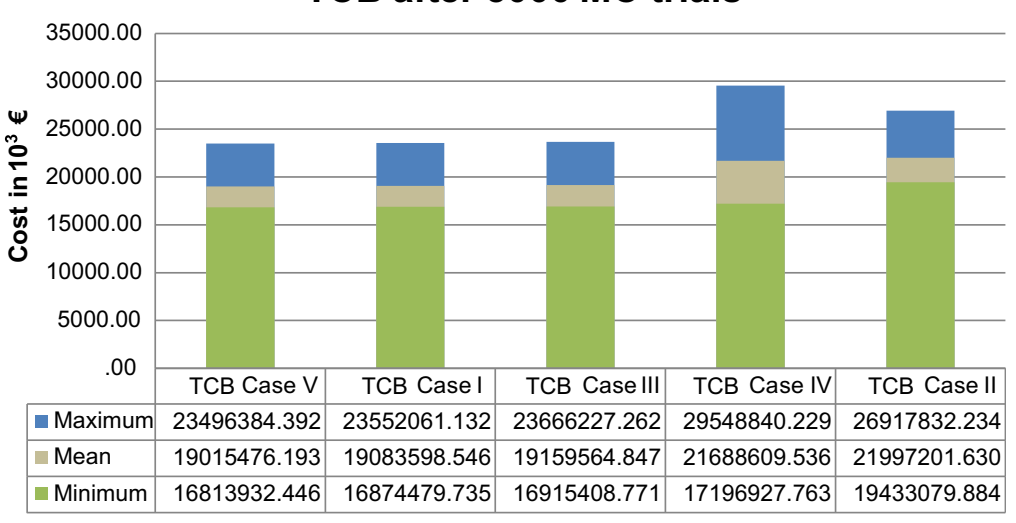

Fig. 4. Monte Carlo analysis results after 5000 trials.

statistical outcome of the Monte Carlo analysis after 5000 trials as per Crystal Ball software; Table 9 gives the contribution to the variance of certain assumptions. These assumptions are given in the first column and correspond to the uncertain parameters as described in Table 5.

When Fig. 3 (outcome of the basic economic model) and Fig. 4 (results of the Monte Carlo simulation) are compared we observe an increase in absolute values of the TCBs while the ranking of the cases remains undisturbed. The uncertainty parameters (Table 5) take mainly into account an increase in the cost of steel, coating, aluminum and zinc over the 25 years to come. If the range and distribution model of these variables are assumed correctly this is reflected by a rise of the mean value of the TCBs with an average of $20 \%$ without a change in the relative relation of the cases.

The values shown in Table 9 are the percentages variance or uncertainty in the target forecast due to the respective assumptions. Items with a positive contribution have a positive value; this reflects a direct relationship between the item and the TCB. Items with a negative value have an inverse relationship.

Only three assumptions are worth mentioning. The influence of the steel price is decisive for all cases. A total of $20 \%$ of the variance of the TCB of Case III is due to the cost of TSCF 25 and the TCB of case IV is mainly affected by the price of CRS.

\section{Discussion}

Based on the reference model and supported by the sensitivity analysis and the Monte Carlo simulation the increased scantling technique, applied in case II, can be classified as economically not

Table 8

Statistical outcome of the Monte Carlo analysis after 5000 trials.

\begin{tabular}{llllll}
\hline Statistics & TCB Case I & TCB Case II & TCB Case III & TCB Case IV & TCB Case V \\
\hline Trials & 5000 & 5000 & 5000 & 5000 & 5000 \\
Mean & $19,083,599$ & $21,997,202$ & $19,159,565$ & $21,688,610$ & $19,015,476$ \\
Median & $18,974,364$ & $21,876,340$ & $19,059,431$ & $21,548,482$ & $18,906,595$ \\
Mode & - & - & - & - & - \\
Standard deviation & $1,103,677$ & $1,250,232$ & $1,064,975$ & $1,963,763$ & $1,103,431$ \\
Variance & $1,218,102,868,859$ & $1,563,080,502,415$ & $1,134,172,277,275$ & $3,856,365,805,060$ & $1,217,559,756,106$ \\
Skewness & 0 & 0 & 0 & 0 & 0 \\
Kurtosis & 3 & 3 & 3 & 3 & 3 \\
Coeff. of variability & 0 & 0 & 0 & 0 & 0 \\
Minimum & $16,874,480$ & $19,433,080$ & $16,915,409$ & $17,196,928$ & $16,813,932$ \\
Maximum & $23,552,061$ & $26,917,832$ & $23,666,227$ & $29,548,840$ & $23,496,384$ \\
Range width & $6,677,581$ & $7,484,752$ & $6,750,818$ & $12,351,912$ & $6,682,452$ \\
Mean std. error & 15,608 & 17,681 & 15,061 & 27,772 & 15,605 \\
\hline
\end{tabular}


Table 9

Sensitivity data of the Monte Carlo analysis.

\begin{tabular}{llllll}
\hline Assumptions & TCB case I & TCB case II & TCB case III & TCB case IV & TCB case V \\
\hline Drydock/day & 0 & 0 & 0 & 0 & 0 \\
Grade A basis & 94.1 & 94.7 & 88.8 & 44.3 & 94.2 \\
Initiele cost PSPC 15 or TSCF 25 & 5.5 & 4.3 & 10.9 & 1.1 & 5.5 \\
Price aluminium anodes in $€ / \mathrm{kg}$ & 0 & 0 & 0 & 0 & 0 \\
Price anodes in $€ / \mathrm{kg}$ & 0 & 0 & 0 & 0.00 & 0 \\
Relation grade A - CRS & 0.1 & 0.1 & 0.1 & 54.6 & 0.1 \\
Time charter equivalent & 0 & 0.6 & 0 & 0 & 0.2 \\
Inflation rate & 0.2 & 0.3 & 0.2 & 0 & 100 \\
Total & & 100 & & & 100 \\
\hline
\end{tabular}

healthy. Expanded scantlings offer adequate protection against corrosion but the penalty of an increased lightweight and consequently the loss of cargo carrying capacity is simply too important. This conclusion is a confirmation of Eliasson's [46] statement, it is possible to build ships with such thick steel that even with free corrosion taking place the ship would have enough strength left to perform its designed service life but that It is generally agreed today that this is no longer a cost efficient way to build and operate ships.

Construction methods I, III and V are matched and the correct choice will be dependent upon a lot of parameters, the most important being the steel price and the coating cost. The use of corrosion resistant steel, simulation IV, becomes attractive if the cost of CRS comes down till maximum 1.1 times the cost of ordinary grade A steel. A reduction with approximately $20 \%$ on the model CRS cost.

Case I, the way we are actually constructing ballast tanks is not the worst of solutions taken into consideration that there is still a lot of room for improvement.

The average degradation rate of the coating used in the economic model is probably too high. $1.7 \%$ surface degradation per year is based on our database of 140 ships ranging from 0 to more than 40 years of age. A follow-up study to determine a sound corrosion rate is needed with a focus on PSPC ships without considering older non-PSPC ships.

The average durability of $\mathrm{PSPC}_{15}$ coating can be increased substantially if sufficient attention is given to surface preparation and application conditions.

Case V is a logical evolution of case I. The sacrificial $\mathrm{Zn}$ anodes have been replaced by aluminum anodes and the weight has been increased to last the full economic lifespan of the ship.

Zinc has been in use as a sacrificial anode for longer than aluminum and is considered the traditional anode material. However, aluminum has several outstanding advantages as a sacrificial anode material and is fast becoming the material of choice [47].

The replacement of zinc by aluminum is ecological beneficial. The negative impact of zinc on the marine environment is well known and documented while this is not the case for aluminum. Aluminum is not considered a pollutant.

However, there are also some drawbacks regarding the use of aluminum as sacrificial material in ballast tanks adjacent to tanks for liquid cargo with flash point $<60^{\circ} \mathrm{C}$. According to DNV Rules for Ships such tanks are considered dangerous areas. Aluminum alloyed anodes are to be so located that a kinetic energy of $\leq 275 \mathrm{~J}$ is developed in case of their falling down. That means that an aluminum anode weighing for instance $10 \mathrm{~kg}$ must be located lower than $2.8 \mathrm{~m}$ from the tank bottom or stringer deck.

In a forgoing study [3] we demonstrated that sacrificial anodes are only beneficial if they are installed and maintained in a correct way. Practical experience after many tank surveys indicated that this is not very often the case.

Economically, Case III, the use of a superior paint, seems to be the most promising way forward. A lot of field remains to be covered. What such an improved paint system should look like is still far from clear. Our field research indicates mechanical damage and cracking, besides application shortcomings, as primary cause of corrosion. A protective coating can be made more resistant to deformations by the addition of fibers. Natural or synthetic fibers will be used to mechanically reinforce formulations 
increasing fatigue properties, strength, and flexibility improving corrosion resistance and increasing the service life of coating.

Also, the performance of $\mathrm{TSCF}_{25}$, used in this study, is questioned by certain shipyards. A Dutch shipyard (which requested to stay anonymous) mentioned as follows: "the wish to reduce and eventually completely eliminate, the maintenance in ballast tanks is fully understandable. I am not aware of any independent scientific proof that the complete removal of the shop primer, the reduction of the allowable quantity of dust, a lowering of the maximal chloride pollution from 50 to $30 \mathrm{mg} / \mathrm{m}^{2}$, the increase of the layer thickness from 320 to 350 (90/10) micron and three full coats instead of two will result in an increase of life span of $67 \%$."

Case IV studies the use of corrosion resistant materials instead of grade A steel. It is assumed here that CRS will live up to the promised characteristics. At this moment these steel varieties are in an experimental phase and the exact features still remain to be established. Also, the exact retail price is unknown at present. The estimations used in this study are indicative and only based on the value of the composing alloy elements. It is almost certainly that when the demand for this product increases, the retail price will follow.

The data used in this model are an approximation of reality. They provide a platform to compare the different cases and should not be considered as true costs. Huge differences exist and prices vary in function of geographical location, time and availability. Since the basic commodities are becoming scarcer, the steel price will keep on rising. The CRS obtains its qualities by adding, amongst others, chromium and molybdenum, both becoming increasingly scarce. These arguments are favoring the use of improved coating systems. However, the coating cost is very sensitive. A little change in the cost of $\mathrm{TSCF}_{25}$ is capable of reversing the economical ranking of the hypothetical cases.

\section{Conclusion}

At this moment the best way to protect ballast tanks is by applying a standard PSPC $_{15}$ coating on a perfectly prepared substrate and under good application conditions. Lifetime lasting aluminum anodes could then be used as a backup system, if they are well distributed across the ballast tank and properly maintained.

In addition, the most promising line of research seems to be dealing with the development of an improved paint system with increased resistance to impact damage.

\section{References}

[1] Koch GH, Brongers MPH, Thompson NG, Vimani YP, Payer JH. Corrosion costs and preventive strategies in the United States. US Federal Highway Administration; 2002. Report FHWA-RD-01-156.

[2] Johnson J. Cost of corrosion in ships, report. Dublin, Ohio: CC Technologies Laboratories, Inc.; 2001.

[3] De Baere K, et al. In situ study of the parameters quantifying the corrosion in ballast tanks and an evaluation of improving alternatives, NACE Conference Papers, Houston; 2011.

[4] Melchers RE. Corrosion uncertainty modelling for steel structures. Journal of Constructional Steel Research 1999;52:3-19.

[5] Wang GE, et al. Estimation of corrosion rates of structural members in oil tankers. Proceedings of 22nd international conference on offshore mechanics and arctic engineering; 2003.

[6] Tator KB. Risk assessment and economic considerations when coating ballast tanks. Workshop: coatings for corrosion protection: offshore oil and gas operation facilities, marine pipeline and ship structures, Mississippi, USA; 2004.

[7] Brown RS, Savage I. The economics of double hulled tankers. Maritime Policy and Management 1996;23:167-75.

[8] Oil Pollution Act, Public Law No 101-380 (33 U.S.C. 2701 et seq.), 104 Stat. 484; 1990.

[9] Kim I. Ten years after the enactment of the Oil Pollution Act of 1990: a success or a failure. Marine Policy 2002;26:197-207.

[10] Lloyds register, tanker focus1. p. 12.

[11] Safinah News lettre. "Equivalent" ballast tank protection; March 2009. Available from: http://www.safinah.co.uk/news/ equivalent-ballast-tank-protection.htm [last accessed August 1, 2011].

[12] Smoljko I, et al., Some new studies of sacrificial anodes. First world congress on corrosion in the military; 2007.

[13] Vantorre M. Afmetingen en grootte van schepen. University Gent; 2011-2012. Unpublished.

[14] IMO, IMO Resolution MSC. 215(82), Performance standard for protective coatings for dedicated seawater ballast tanks in all types of ships and double-side skin spaces of bulk carriers, IMO Naval Architectural Group - Maritime Safety Committee [adopted 8 December 2006].

[15] Verstraelen H, De Baere K, Schillemans W, Lemmens L, Dewil R, Lenaerts S, et al. In situ study of ballast tank corrosion on ships-part 1. Materials Performance 2009;48(10):48-51.

[16] Verstraelen H, De Baere K, Schillemans W, Lemmens L, Dewil R, Lenaerts S, et al. In situ study of ballast tank corrosion on ships-part 2. Materials Performance 2009;48(11):54-7. 
[17] Gratsos GA, Zachariadis P. Life cycle cost of maintaining the effectiveness of a ships structure and environmental impact of ships design. Hellenic Chamber of Shipping; 2007.

[18] Guidance notes on the inspection, maintenance and application of marine coating systems. 3rd ed.ABS; 2007.

[19] SHELL, Ballast tanks: an overview of the TSCF guidelines for ballast tank coating systems and surface preparation. Tanker structure cooperative forum, shipbuilders meeting, Tokyo; 2000.

[20] Aloui R. Development of a generalized life cycle cost/earning model for tanker ship structure based on effective cost assessment of the corrosion, maintenance and scantling design variables. Master thesis, Université de Liège (ANAST), 2010, unpublished; 2010.

[21] Paik JK, Kim DK. Advanced method for the development of an empirical model to predict time-dependent corrosion wastage. Corrosion Science 2012;63:51-8.

[22] Paik JK, et al. A time-dependent corrosion wastage model for seawater ballast tank structures of ships. Corrosion Science 2004;46:471-86.

[23] Guo J, et al. Time-varying ultimate strength of aging tanker deck plate considering corrosion effect. Marine Structures 2008:1-18.

[24] Southwell CR, Bultman JD, Hummer CW. Estimating of service life of steel in seawater, seawater corrosion handbook. Noyes Data Corporation; 1979.

[25] Guedes Soares C, Garbatov Y. Reliability of maintained, corrosion protected plates subjected to non-linear corrosion and compressive loads. Marine Structures 1999;12:425-55.

[26] Qin SP, Cui WC. Effect of corrosion models on the time-variant reliability of steel plated elements. Marine Structures 2003; $16: 15-34$.

[27] Ivanov LD, Wang GE, Seah AK. Evaluating corrosion wastage and structural safety of aging ships. In: Pacific international maritime conference, Sydney, Australia; 2004.

[28] IACS. Common structural rules for tankers and bulk carriers. London, UK: International Association of Classification Societies; 2005.

[29] Wang GE, et al. A statistical investigation of time-variant hull girder strength of aging ships and coating life. Marine Structures 2008;21:240-56.

[30] Kawano H, Hirakata M. Tanker structure and hull failure strength, PAJ oil spill symposium 2003. Tokyo: Petroleum Association of Japan; February 27-28, 2003.

[31] Løseth R, Sekkesæter G, Valsgård S. Economics of high-tensile steel in ship hulls. Marine Structures 1994;7:31-50.

[32] Baldwin L. Techno-economic assessment of new coating application for new-building marine production. PhD thesis, University of Newcastle Upon Tyne; 1995.

[33] Directorate for Science, Technology and Industry (STI) - compensated gross ton system. OECD; 2006.

[34] McNulty P. Life cycle cost of the Venturi oxygen stripping ballast tank corrosion protection system in double hull ships. Los Angeles, USA: NEI Treatment Systems [last accessed August 1, 2011], http://www.nei-marine.com/doc/pub/PeterMcNulty_ LifeCycleCost_VOS_Panamax.pdf; 2007.

[35] Boardman AE, Greenberg DH, Vining AR, Weimer DL. Cost-benefit analysis. Upper Saddle River, New Jersey: Pearson Eduction, Inc.; 2006.

[36] Al-Mansour F, Kozuh M. Risk analysis for CHP decision making within the conditions of an open electricity market. Energy 2007.

[37] Eurostat, Available from: http://www.epp.eurostat.ec.europa.eu/statistics_explained/index.php/Consumer_prices-inflation_ and_comparative_price_levels [as per February 2012].

[38] Harmonized indices of consumer prices $(2005=100)$ - monthly data (12-month average rate of change). Available from: http://www.google.be/url?sa=t\&rct=j\&q=\&esrc=s\&source=web\&cd=5\&cad=rja\&ved=0CFsQFjAE\&url=http\%3A\%2F\% 2Fwww.teko.sk\%2Fc\%2Fdocument_library\%2Fget_file\%3Fuuid\%3D12c2653b-93a7-4521-9d86-6d8be224bf6a\%26groupId\% 3D10136\&ei=Q5ksUPXfD8HIhAf7wIHYDQ\&usg=AFQjCNH_Is6w9uf1qDwuoJ-pcr4mnm9pVQ\&sig2=aBcSlDrMZDuQXFE7jtySQ.

[39] European Maritime Safety Agency. Double hull tankers, high level panel of experts report. Lisbon: European Maritime Safety Agency; June 2005.

[40] Community of European Shipyard associations, Report 24; September 2011.

[41] Impact assessment guidelines. European Commission; 2009.

[42] Eijgenraam CJJ, Koopmans CC, Tang PJG, Verster ACP. Evaluatie van infrastructuurprojecten: leidraad voor kosten-batenanalyse. Centraal Planbureau: Nederlands Economisch Instituut; 2000.

[43] Pearce, et al., The standard discounting rate EU; 2003. Available from: http://www.ec.europa.eu/governance/impact/.

[44] Pearce D, Groom B, Hepburn C, Koundouri P. Valuing the future: recent advances in social discounting. World Economics 2003;4:121-41.

[45] Psarros GA, Vassalos D. Effectiveness of corrosion measures to bulk carriers with Life Cycle Cost Analysis. International Shipbuilding Progress 2009;56:95-118.

[46] Eliasson Johnny. Prevention and management of marine corrosion. London: Lloyd's List Event Conference; 2003.

[47] Cuproban, Available from: http://www.cuproban.com/anodes.htm [as per January 2012].

[48] Unknown, The Physics Factbook, Available from: http://www.hypertextbook.com/facts/2004/KarenSutherland.shtml [last accessed July 2012].

[49] McNulty P. Alternatives to PSPC. Los Angeles, USA: NEI Treatment Systems [last accessed August 1, 2011], http://www.neimarine.com/doc/pub/PeterMcNulty_Alternatives_PSPC1.pdf; 2008.

[50] The A-Z of cathodic protection. Available from: http://www.z-guard.co.uk/zguardcart/product2.asp?pid=410 [last accessed December 2011].

[51] Arab Shipbuilding and Repair Yard Company. Available from: http://www.asry.net [last accessed December 2011].

[52] Legacy Shipbroking S.A., Market report; 23-29 August 2010. 